\title{
Deteksi Dini Oral Squamous Sel Carcinoma (OSCC) dengan Menggunakan Human Papillomavirus (HPV) sebagai Penandanya
}

\author{
Pranata $\mathbf{N}^{\mathbf{1}}$ \\ 1. Falkutas Kedokteran Gigi, Universitas Kristen Maranatha, 40164, Indonesia \\ Email: natallia.pranata@dent.maranatha.edu; pranatanatallia@gmail.com
}

\begin{abstract}
Abstrak
Insidensi oral squamous cell carcinoma (OSCC) secara global diprediksi akan meningkat sekitar $62 \%$ pada tahun 2035. Salah satu pathogen yang dapat menyebabkan keganasan adalah human papillomavirus (HPV). Pada kasus OSCC sekitar 17\% hingga $87 \%$ diakibatkan oleh infeksi HPV. ${ }^{1-3}$ OSCC memiliki prognosis yang baik jika terdeteksi pada tahap dini. Deteksi HPV pada OSCC menjadi biomarker penting, dan dapat digunakan sebagai screening populasi memiliki resiko terkena OSCC.
\end{abstract}

Kata kunci: E6, E7, human papillomavirus, oral squamous cell carcinoma, CLART HPV Assay

\section{Pendahuluan}

Keganasan telah menjadi penyebab kematian yang lebih sering dibandingkan dari penyakit kardiovaskuler atau stroke. Berdasarkan Data GLOBOCAN, International Agency for Research on Cancer (IARC) diketahui bahwa pada tahun 2012 terdapat 14.067.894 kasus baru dan 8.201.575 kematian akibat kanker kanker rongga mulut dan bibir di seluruh dunia. ${ }^{4}$ Berdasarkan hasil riskesdas 2007, di Indonesia terdapat 986.532 kasus keganasan pada bibir, rongga mulut dan faring. ${ }^{5}$ Angka ini secara global pada tahun 2035 diprediksi akan meningkat $62 \%{ }^{1}$

Keganasan pada bibir, rongga mulut dan faring 95\% adalah oral squamous cell carcinoma (OSCC). Secara klinis terlihat sebagai lesi ulseratif dengan indurasi pada bagian tepinya, terlihat lebih merah dari sekitarnya. Mayoritas dari OSCC terdiagnosis pada tahap lanjut, pada fase III atau IV. Hal ini sangat mempengaruhi survival rate dan kualitas kehidupan. Terapi yang tersedia saat ini, eksisi jaringan ganas dan kombinasi radioterapi dengan kemoterapi, namun survival rate untuk 5 tahun sangat rendah, hanya sekitar 50-60\%.6,7 Pasien yang terdiagnosis pada tahap lanjut memiliki respon yang buruk terhadap terapi dan tingkat kekambuhan yang tinggi. ${ }^{6}$ OSCC memiliki prognosis yang baik jika terdeteksi pada tahap dini. ${ }^{7}$

Penyebab keganasan secara umum dapat dibagi menjadi dua, yaitu faktor lingkungan dan genetik herediter. Faktor lingkungan dapat menginisiasi atau menjadi promotor terjadinya mutasi genetik pada sel. Contohnya tembakau, alkohol, radiasi matahari, polusi lingkungan, pola diet dan obesitas, pola hidup yang tidak sehat, obat-obatan, dan infeksi. Lingkungan rongga mulut yang juga diduga menjadi inisiator atau promotor keganasan misalnya oral higiene yang buruk, periodontitis kronis, karies pada gigi sehingga ada bagian gigi yang tajam menjadi trauma kronis bagi jaringan sekitarnya, bahan medikasi dan restorasi yang karsinogenik, dan patogen infeksius. ${ }^{2,8,9}$ Pada beberapa penelitian patogen yang dapat menyebabkan keganasan adalah human papillomavirus (HPV). ${ }^{10,11}$ Pada kasus OSCC sekitar 17\% hingga 87\% diakibatkan oleh infeksi HPV. ${ }^{1-3}$ 
Banyak penelitian telah dilakukan untuk mendeteksi keberadaan HPV, bahkan pada keadaan sebelum terjadinya keganasan, termasuk pada mukosa mulut normal. ${ }^{8,9,12}$ Analisis terhadap pemeriksaan DNA HPV, pada penelitian yang mempelajari patogenesis keganasan, dari sejak keadaan mukosa mulut normal hingga terjadinya keganasan, menunjukkan rate HPV yang semakin meningkat. ${ }^{3}$ Deteksi HPV dapat digunakan sebagai screening suatu populasi mempunyai resiko mengalami OSCC.,13

\section{Struktur HPV}

Human papillomavirus (HPV) adalah nonenveloped virus, memiliki genom yang sirkuler double stranded (DNA), terdiri dari 8000 pasang basa (base pairs/ bp), yang dapat mengkode lebih dari sepuluh protein. HPV genom terdiri dari tiga region, sekitar 4000 bp mengkode protein yang terlibat pada replikasi virus dan transformasi sel, berikutnya 3000 bp mengkode struktur protein virus, dan 1000 bp adalah daerah yang tidak mengkode protein, namun merupakan regulator untuk virus replikasi dan transkripsi. ${ }^{11}$ Berdasarkan urutan mengkode atau mengekspresikan protein, genom ini dibagi menjadi dua, yaitu gen-gen yang mengkode protein awal (early genes) dan gengen yang mengkode protein belakangan (late genes). ${ }^{14,15}$ Setiap protein pada HPV mempunyai fungsi untuk mendukung kehidupan virus tersebut, fungsi dari masingmasing protein disebutkan pada Tabel $1 .^{16,17}$

Tabel 1 Fungsi Protein pada HPV. ${ }^{17}$

\begin{tabular}{ll}
\hline Protein & Fungsi \\
\hline HPV & Protein-protein Awal (Early Proteins) \\
E1 & Inisiasi replikasi genom virus \\
E2 & Replikasi dan transkripsi DNA virus \\
& Segregasi genom virus \\
E4 & Pengepakan genom virus \\
& Maturasi partikel virus \\
E5 & Oncoprotein \\
& Terlibat dalam transformasi sel inang dan menghambat apotosis \\
& pada fase akhir karsinogenesis \\
E6 & Oncoprotein mayor \\
& Inaktivasi protein p53 \\
E7 & Menghambat apotosis \\
& Oncoprotein mayor \\
& Inaktivasi protein pRB \\
Protein-protein belakangan (Late Proteins) \\
L1 & Protein mayor kapsid \\
L2 & Protein minor kapsid \\
\hline
\end{tabular}




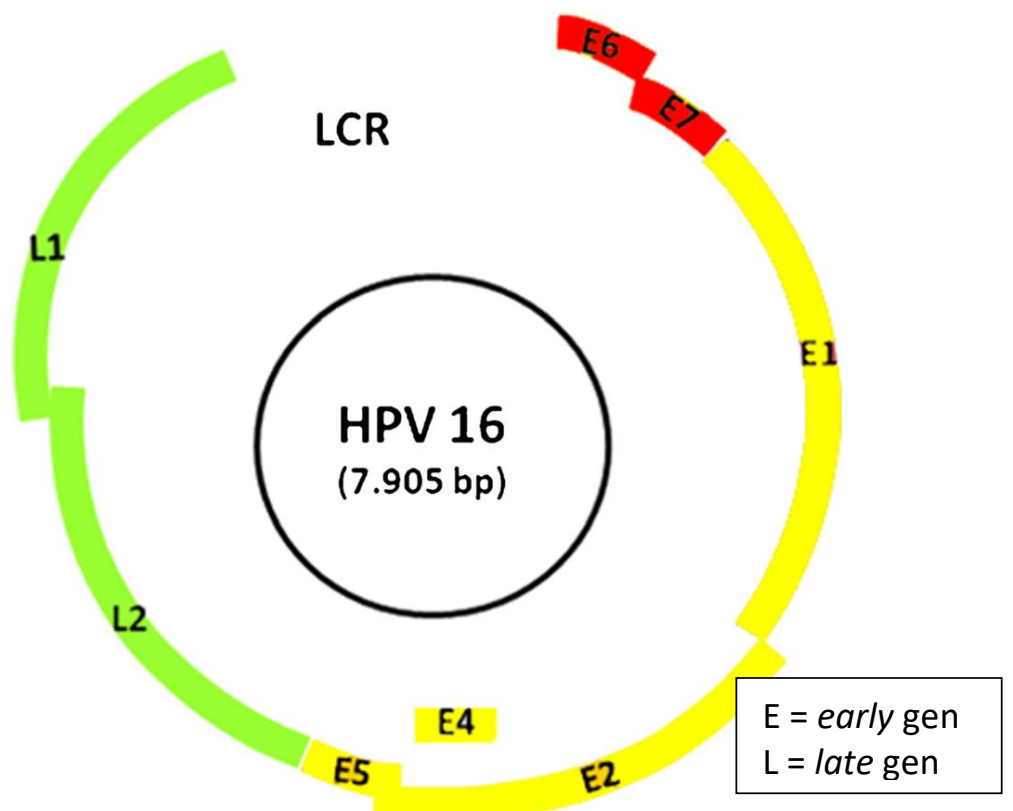

Gambar 1. Organisasi Genom HPV. ${ }^{15}$

\section{Siklus Hidup HPV}

Target sel untuk HPV adalah basal sel (Gambar 2), karena masih memiliki kapasitas proliferasi yang masih tinggi, sehingga dapat mendukung replikasi virus tersebut. ${ }^{18}$ Pada mukosa mulut terdapat tempat dimana sel-sel basal langsung terpapar dengan lingkungan luar, yaitu pada poket periodontal. Poket periodontal merupakan keadaan patologis pada jaringan periodontal atau jaringan pendukung gigi, yaitu bertambah dalamnya sulkus gusi, melebihi $3 \mathrm{~mm}$, terlihat pada Gambar 3 sehingga diduga tempat ini menjadi reservoir yang ideal bagi HPV. ${ }^{8,9}$

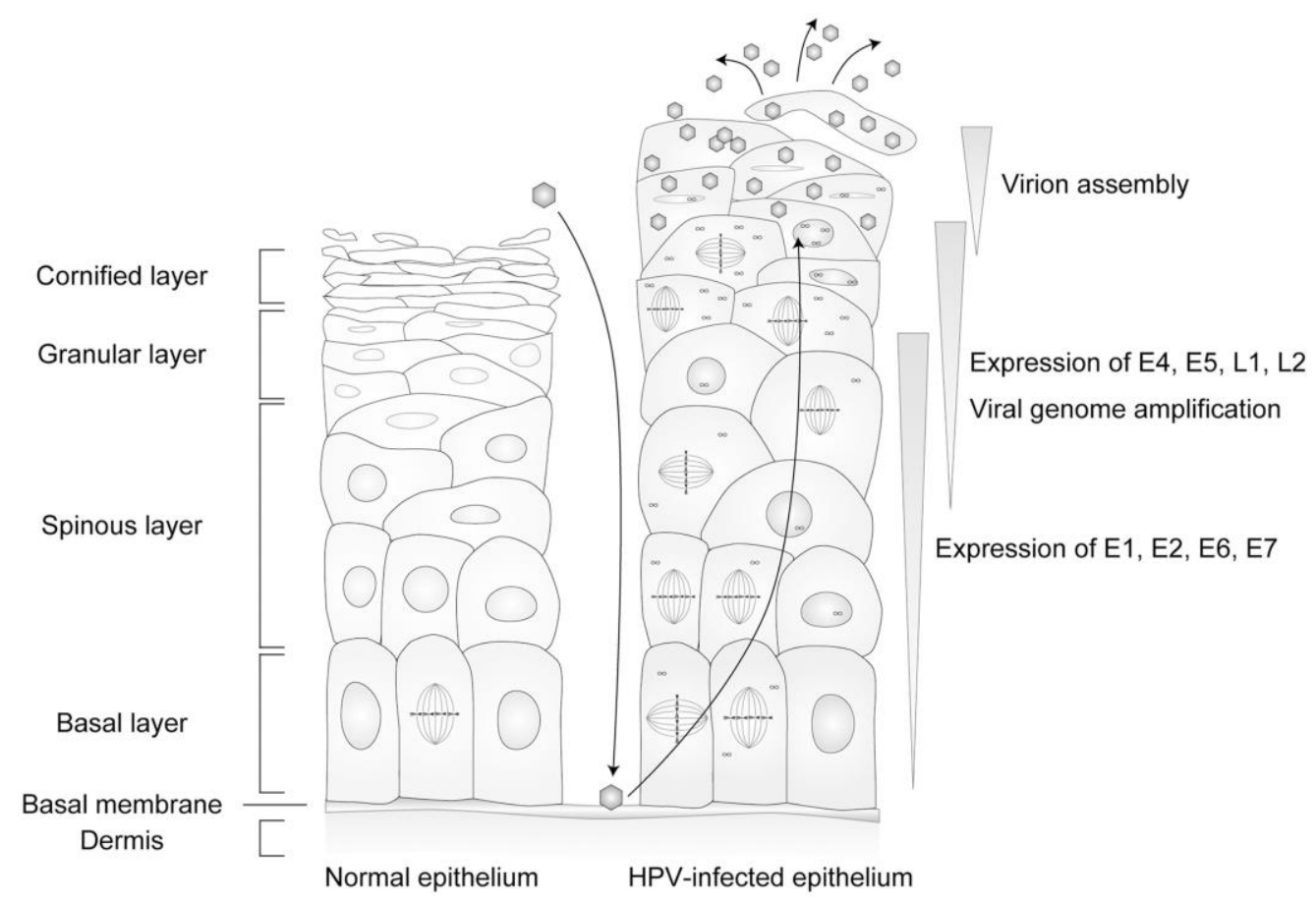


Gambar 2 Infeksi HPV pada Epitelium. ${ }^{3,18}$

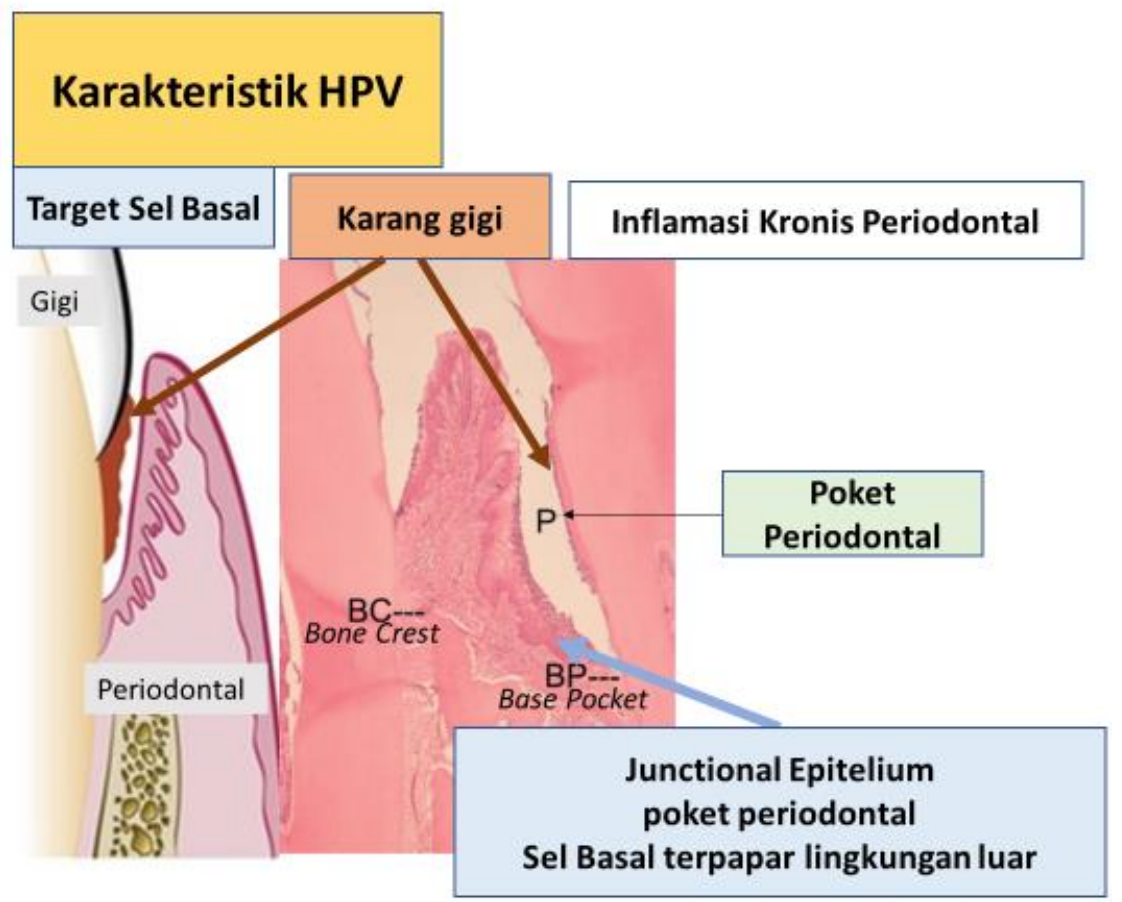

Gambar 3 Sel-sel Basal terpapar Lingkungan Luar pada Poket Periodontal. ${ }^{19}$

Sel-sel pada lapisan basal setelah keluar dari siklus sel, akan mulai masuk ke tahap diferensiasi, ketika ini terjadi pada sel yang telah terinfeksi HPV, maka E6 dan E7 dari HPV akan menginaktivasi p53 and retinoblastoma protein sel tersebut, sehingga sel memungkinkan masuk kembali ke siklus sel. Sel ini kembali bermitosis namun telah disisipi materi genetik dari HPV. Hal ini berjalan seiring dengan perjalanan sel mencapai lapisan paling luar hingga mengalami deskuamasi. Ketika deskuamasi sel terjadi, virion juga akan keluar ke lingkungan ekternal. ${ }^{18}$ Infeksi HPV bersifat laten, tidak terjadi langsung setelah HPV masuk ke dalam sel, sehingga diperlukan sampel yang mampu menyimpan data biologis rongga mulut yang cukup lama. ${ }^{8,9,17}$

Siklus sel di regulasi oleh kompleks cyclin dan cyclin dependent kinase (CDKs). Pada fase G1 sebelum lanjut ke fase S, terdapat G1 restriction point, pada Gambar 4, digambarkan dengan bar warna merah. ${ }^{16} \mathrm{Hal}$ ini dikontrol oleh retinoblastoma (RB). RB pada keadaan tidak aktif berikatan dengan E2F. Protein utama yang terkait dengan karsinogenesis adalah E6 dan E7. Protein E6 akan berikatan dan mendegradasi p53. Ikatan antara E6 dan p53 akan menyebabkan p53 kehilangan fungsi sebagai gen tumor supresor yang bekerja di fase G1. Gen p53 akan menghentikan siklus sel di fase G1, tujuan penghentian siklus sel adalah agar sel dapat memperbaiki kerusakan sebelum berlanjut ke fase S. Mekanisme kerja p53 adalah dengan menghambat kompleks $c d k$ cyclin yang akan menstimulasi sel memasuki fase selanjutnya, ketika E6 berikatan dengan p53 akan menyebabkan sel tetap lanjut ke fase berikutnya, walaupun terjadi kerusakan DNA. Jalur yang digunakan p53 melalui p21 yang akan melawan aktivitas kompleks $c d k$-cyclin, karena itu inaktivasi p53 mengakibatkan jalur regulasi p21 terganggu. Sedangkan E7 akan berikatan dengan pRB. Seharusnya pRB berikatan dengan E2F. Ikatan pRB-E2F menghambat sel keluar dari fase G1. E2F akan mempengaruhi siklus sel melalui aktivasi protoonkogen $c-m y c$. Siklus sel yang tidak 
terkontrol menyebabkan proliferasi sel yang melebihi batas normal sehingga sel tersebut berubah menjadi sel ganas..$^{11,16,17}$

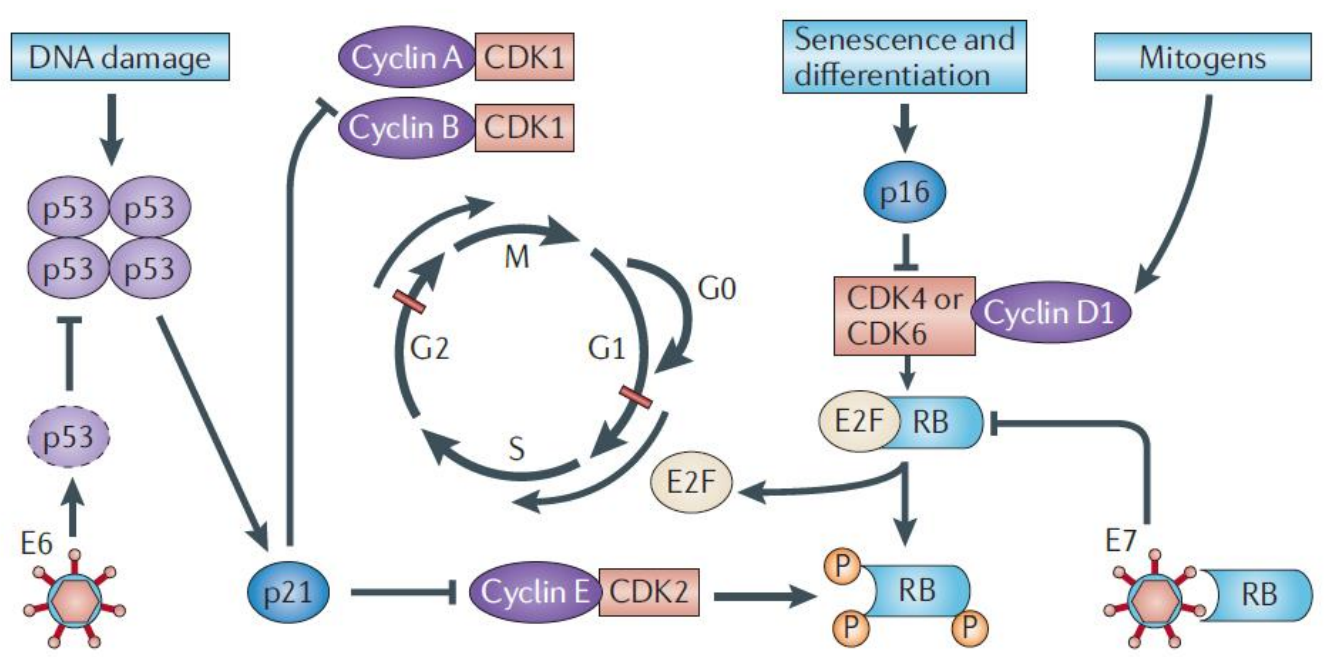

Gambar 4 Deregulasi Siklus Sel oleh HPV. ${ }^{16}$

\section{Infeksi HPV sebagai Faktor Etiologi OSCC}

Berdasarkan teridentifikasinya HPV, OSCC dibagi menjadi dua yaitu HPV positif dan HPV negatif, perbedaannya terlihat pada Tabel 2. HPV positif mempunyai prognosis yang lebih baik. ${ }^{3,14,16}$ Protein E6 dari HPV hanya menghambat aktivasi p53 sehingga TP53 pada OSCC dengan HPV positif sangat jarang ditemukan dalam keadaan mutasi. $^{2,16,17}$ Deteksi HPV, pada OSCC menjadi biomarker yang sangat menentukan untuk menetapkan etiologi, diagnosis, dan prognosis. ${ }^{13}$

Tabel 2 Perbedaan HPV Negatif dan Positif pada Head and Neck Squamous Cell Carcinoma (HNSCC). ${ }^{16}$

\begin{tabular}{lll}
\hline Kategori & HPV Negatif & HPV Positif \\
\hline Insidensi & Menurun & Meningkat \\
Etiologi & Merokok, alcohol berlebihan & Oral sex \\
$\begin{array}{l}\text { Umur } \\
\text { Mutasi TP53 }\end{array}$ & Diatas 60 tahun & Kurang dari 60 tahun \\
$\begin{array}{l}\text { Tempat } \\
\text { sering terkena } \\
\begin{array}{l}\text { Prognosis } \\
\hline\end{array}\end{array}$ & Sering & Jarang \\
& Tidak ada & Oropharynx \\
\hline
\end{tabular}

Banyak penelitian telah dilakukan untuk mendeteksi keberadaan HPV, bahkan pada keadaan sebelum terjadinya keganasan, termasuk pada mukosa mulut normal. ${ }^{8,9,12}$ Analisis terhadap pemeriksaan DNA HPV, pada penelitian yang mempelajari patogenesis OSCC, menunjukkan rate HPV yang semakin meningkat (terlihat pada Gambar 5). ${ }^{3}$ Deteksi HPV dapat digunakan sebagai screening populasi resiko tinggi OSCC. ${ }^{1,13}$ 


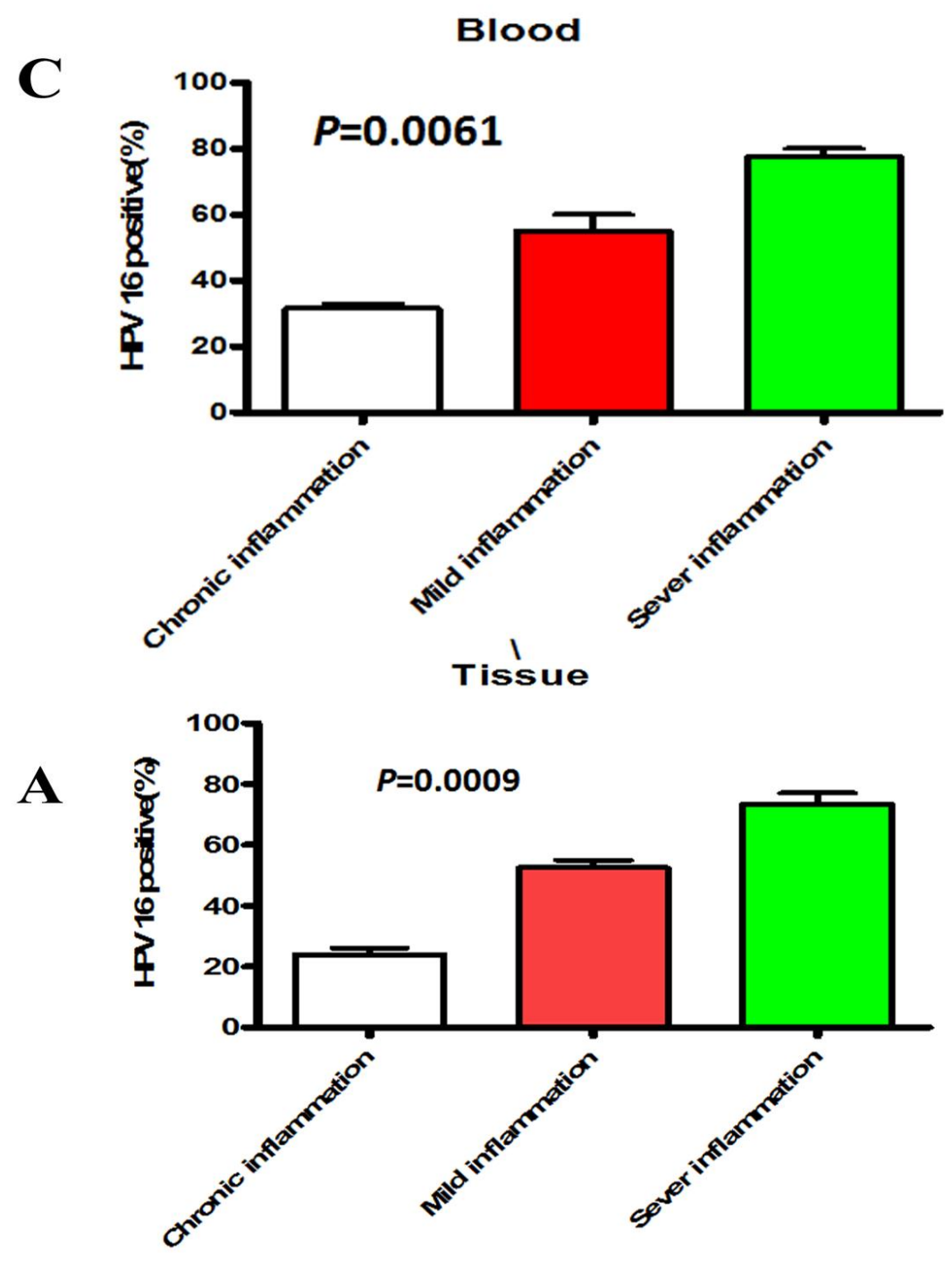

Gambar 5 Infeksi HPV Berkorelasi dengan Inflamasi Kronis. ${ }^{3}$

Pada deteksi dini keganasan, dengan menggunakan keberadaan HPV sebagai markernya, penting untuk mengetahui genotip HPV tersebut, karena berdasarkan berdasarkan keterlibatannya dalam proses karsinogenesis, dibagi menjadi kelompok genotip high risk (HR) dan low risk (LR). Kelompok HR diketahui ada sekitar 12 genotip, terlihat pada Gambar 6 tentang filogenetik HPV, tulisan yang berwarna merah termasuk ke dalam kelompok HR. ${ }^{11}$ Genotip 16 dan 18 yang paling sering menjadi penyebab keganasan. ${ }^{14,17,20}$ 


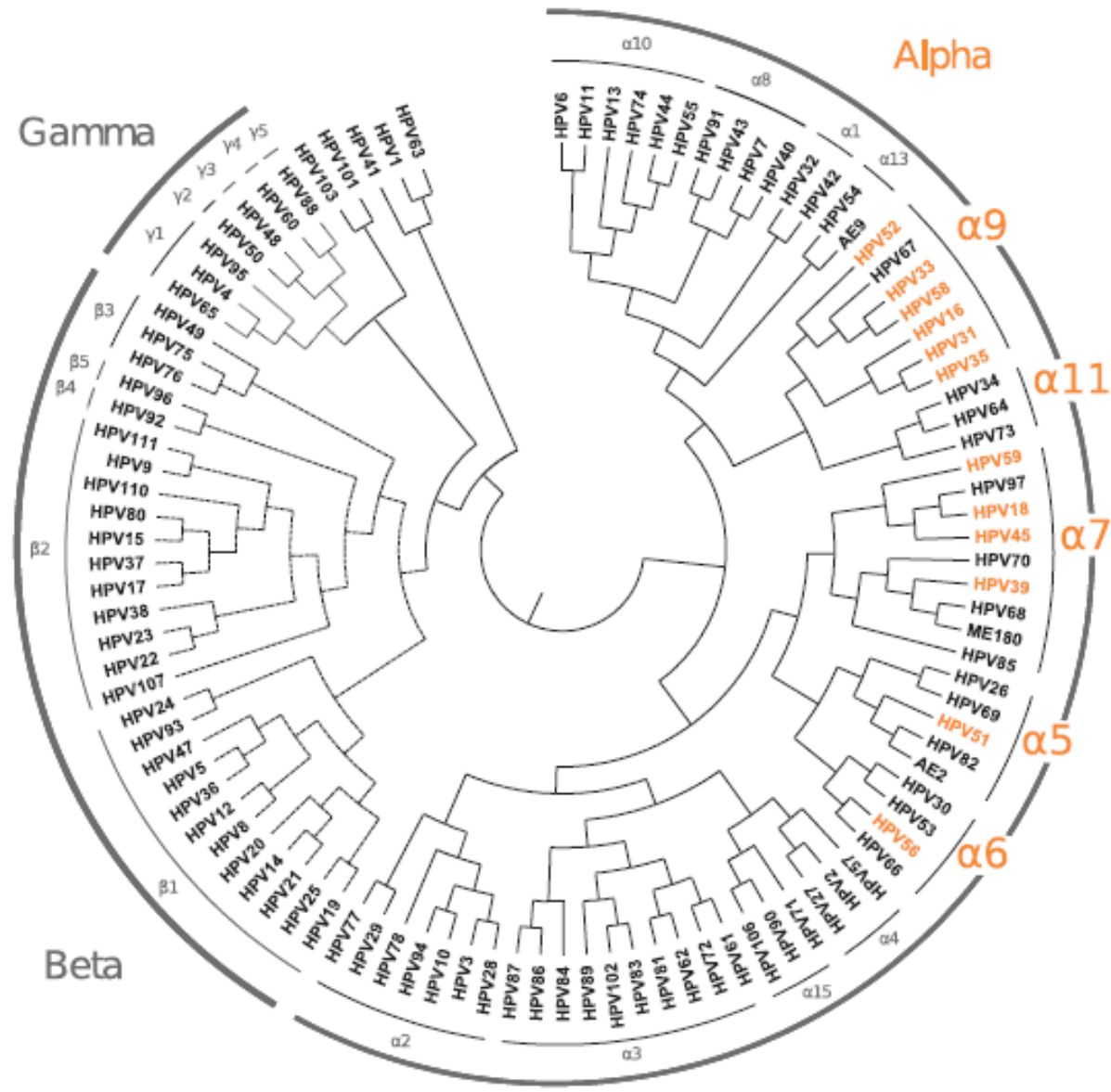

Gambar 6 Filogenetik HPV. ${ }^{11}$

\section{Metode Pemeriksaan HPV}

Baku emas untuk identifikasi HPV dengan pemeriksaan biologi molekular, karena HPV tidak dapat diperbanyak pada kultur jaringan. Pemeriksaan biologi molekular dengan metoda nucleic acid-hybridization assays, signal amplification Assays, dan nucleic-acid amplification (gambar 7). ${ }^{15}$ 


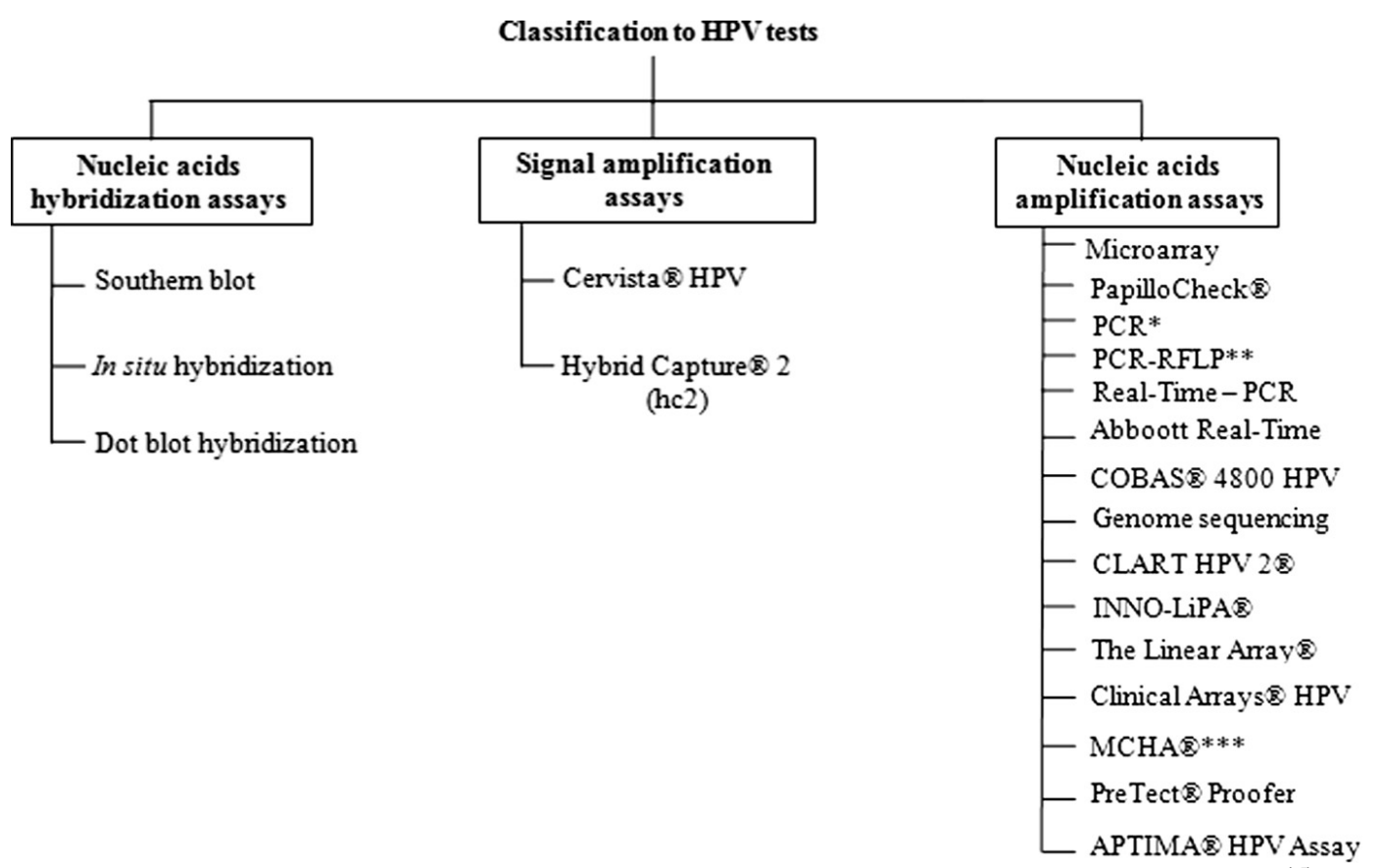

Gambar 7 Diagram Skematik Klasifikasi Metode Pemeriksaan HPV. ${ }^{15}$

Metoda nucleic-acid amplification, dengan polymerase chain reaction (PCR) paling sering digunakan. Agar dapat mendeteksi semua variasi genotip HPV, maka digunakan universal primer HPV yaitu MY09/11. Primer ini mempunyai panjang 450 bp dari gen L1. Bagian ini relatif tidak berubah pada semua genotip HPV sehingga dapat digunakan untuk genotyping HPV. Bagian ini juga disebut conserved region. ${ }^{21}$ Kemudian setelah diamplifikasi, untuk mengetahui tipe HPV tersebut secara spesifik dilanjutkan dengan sekuensing dan dibandingkan datanya dengan GenBank untuk mengetahui genotipnya. ${ }^{21}$ Program yang digunakan adalah National Centre for Biotecnology Information (NCBI) Basic Local Aligment Search Tool (BLAST) secara online pada situs https://blast.ncbi.nlm.nih.gov. ${ }^{22}$

Terdapat beberapa produk komersial yang secara klinis seringkali digunakan sebagai genotyping HPV. Untuk memfasilitasi banyaknya genotip HPV maka dipilihlah CLART HPV2 Assay. CLART HPV2 (Genomica, Madrid, Spain) adalah lowdensity microarray assay dengan prinsip kerja berdasarkan PCR atau amplification genotype specific HPV fragmen L1, $450 \mathrm{bp}$, dari 35 genotip HPV $(6,11,16,18,26,31,33,35$, $39,40,42,43,44,45,51,52,53,54,56,58,59,61,62,66,68,70,71,72,73,81,82$, 83, 84, 85 and 89), visualisasi hasil dianalisis oleh Clinical Array Reader (program komputer). Produk ini juga mempunyai kontrol genomik DNA dan kontrol reaksi amplifikasi. Kontrol genomik DNA menggunakan gen Cystic Fibrosis Transmembrane Conductance Regulator (CFTR), sedangkan kontrol reaksi amplifikasinya menggunakan modifikasi plasmid HPV. ${ }^{23}$

\section{Kesimpulan}

Penyebab OSCC multifaktorial, sekitar 17 hingga $87 \%$ diakibatkan oleh infeksi human papillomavirus (HPV). Infeksi human papillomavirus (HPV) dapat menjadi faktor resiko independen penyebab keganasan. Deteksi HPV, pada OSCC menjadi biomarker yang sangat menentukan untuk menetapkan etiologic sehingga mempengaruhi rencana perawatan prognosis. Analisis terhadap pemeriksaan DNA 
HPV, pada penelitian patogenesis keganasan, menunjukkan rate HPV yang semakin meningkat. Deteksi HPV dapat digunakan sebagai screening populasi memiliki resiko terkena OSCC.

\section{Referensi}

1. Shield KD, Ferlay J, Jemal A, Sankaranarayanan R, Chaturvedi AK, Bray F, et al. The global incidence of lip, oral cavity, and pharyngeal cancers by subsite in 2012. CA Cancer J Clin. 2017;67:51-64.

2. Prayitno A, Rukmo M, Mudigdo A, Dalono D, Asnar E, Rahayu RP, et al. Incidence of HPV infection in oral squamous cell carcinoma and its association with the presence of P53 \& c-myc mutation: a case control study in Muwardi Hospital Surakarta. J Dent Indones. 2010;17:48-52.

3. Liu X, Ma X, Lei Z, Feng H, Wang S, Cen X, et al. Chronic inflammation-related HPV: A driving force speeds oropharyngeal carcinogenesis. Liu X, editor. PLOS ONE. 2015;10:0133681-94.

4. Ferlay J, Soerjomataram I, Dikshit R, Eser S, Mathers C, Rebelo M, et al. Cancer incidence and mortality worldwide: Sources, methods and major patterns in GLOBOCAN 2012: Globocan 2012. Int J Cancer. 2015;136:359-86.

5. Sirait AM. Faktor risiko tumor/kanker rongga mulut dan tenggorokan di Indonesia (Analisis Riskesdas 2007). Media Litbangkes. 2013;23:122-129.

6. Rivera C, Venegas B. Histological and molecular aspects of oral squamous cell carcinoma (Review). Oncol Lett. 2014;8:7-11.

7. Dissanayaka WL, Pitiyage G, Kumarasiri PVR, Liyanage RLPR, Dias KD, Tilakaratne WM. Clinical and histopathologic parameters in survival of oral squamous cell carcinoma. Oral Surg Oral Med Oral Pathol Oral Radiol. 2012;113:518-25.

8. Hormia M, Willberg J, Ruokonen H, Syrjänen S. Marginal periodontium as a potential reservoir of human papillomavirus in oral mucosa. J Periodontol. 2005;76:358-363.

9. Dayakar MM, Shipilova A, Gupta D. Periodontal pocket as a potential reservoir of high risk human papilloma virus: A pilot study. J Indian Soc Periodontol. 2016;20:136-40.

10. Gillison ML, Chaturvedi AK, Anderson WF, Fakhry C. Epidemiology of human papillomavirus-positive head and neck squamous cell carcinoma. J Clin Oncol. 2015;33:3235-42.

11. IARC (2012). Human Papillomaviruses. In: Biological agents. IARC Monogr. 2012;100B:255-315.

12. Shigeishi H, Sugiyama M. Risk factors for oral human papillomavirus infection in healthy individuals: A systematic review and meta-analysis. J Clin Med Res. 2016;8:721-9.

13. Westra WH. Detection of human papillomavirus in clinical samples. Otolaryngol Clin North Am. 2012;45:765-77.

14. Pullos AN, Castilho RM, Squarize CH. HPV infection of the head and neck region and its stem cells. J Dent Res. 2015;94:1532-1543.

15. Abreu AL, Souza RP, Gimenes F, Consolaro ME. A review of methods for detect human papillomavirus infection. Virol J. 2012;9:262-71.

16. Leemans CR, Brakhuis BJM, Brakenhoff RH. The molecular biology of head and neck cancer. Nat Rev Cancer. 2011;11:9-22. 
17. Rampias T, Sasaki C, Psyrri A. Molecular mechanisms of HPV induced carcinogenesis in head and neck. Oral Oncol. 2014;50:356-63.

18. Kajitani N, Satsuka A, Kawate A, Sakai H. Productive lifecycle of human papillomaviruses that depends upon squamous epithelial differentiation. Front Microbiol. 2012;3:1-12.

19. Newman MG, Klokkevold PR, Takei HH, Carranza FA. Carranza's clinical periodontology. 2015.

20. Sasahira T, Kirita T, Kuniyasu H. Update of molecular pathobiology in oral cancer: a review. Int J Clin Oncol. 2014;19:431-6.

21. de Villiers E-M. Cross-roads in the classification of papillomaviruses. Virology. 2013;445:2-10.

22. Johnson M, Zaretskaya I, Raytselis Y, Merezhuk Y, McGinnis S, Madden TL. NCBI BLAST: a better web interface. Nucleic Acids Res. 2008;36:W5-9.

23. Bonde J, Rebolj M, Ejegod DM, Preisler S, Lynge E, Rygaard C. HPV prevalence and genotype distribution in a population-based split-sample study of wellscreened women using CLART HPV2 human papillomavirus genotype microarray system. BMC Infect Dis. 2014;14:413-24. 